\title{
Denaturation and in Vitro Gastric Digestion of Heat-Treated Quinoa Protein Isolates Obtained at Various Extraction pH
}

\author{
Geraldine Avila Ruiz ${ }^{1,2}$ - Mauricio Opazo-Navarrete ${ }^{3}$ - Marlon Meurs ${ }^{2}$. \\ Marcel Minor ${ }^{1} \cdot$ Guido Sala $^{1}$ - Martinus van Boekel ${ }^{2} \cdot$ Markus Stieger $^{4}$. \\ Anja E. M. Janssen ${ }^{3}$
}

Received: 3 March 2016 / Accepted: 7 April 2016 / Published online: 23 April 2016

(C) The Author(s) 2016. This article is published with open access at Springerlink.com

\begin{abstract}
The aim of this study was to determine the influence of heat processing on denaturation and digestibility properties of protein isolates obtained from sweet quinoa (Chenopodium quinoa Willd) at various extraction $\mathrm{pH}$ values $(8,9,10$ and 11). Pretreatment of suspensions of protein isolates at 60,90 and $120^{\circ} \mathrm{C}$ for $30 \mathrm{~min}$ led to protein denaturation and aggregation, which was enhanced at higher treatment temperatures. The in vitro gastric digestibility measured during $6 \mathrm{~h}$ was lower for protein extracts pre-treated at 90 and $120^{\circ} \mathrm{C}$ compared to $60{ }^{\circ} \mathrm{C}$. The digestibility decreased with increasing extraction $\mathrm{pH}$, which could be ascribed to protein aggregation. Protein digestibility of the quinoa protein isolates was higher compared to wholemeal quinoa flour. We conclude that an interactive effect of processing temperature and extraction $\mathrm{pH}$ on in vitro gastric digestibility of quinoa protein isolates obtained at various extraction $\mathrm{pH}$ is observed. This gives a first indication of how the nutritional value of quinoa protein could be influenced by heat processing, protein extraction conditions and other grain components.
\end{abstract}

Geraldine Avila Ruiz and Mauricio Opazo-Navarrete equally contributed to this work

\section{Anja E. M. Janssen}

anja.janssen@wur.nl

1 Food and Biobased Research, Wageningen University and Research Centre, P.O. Boxs 17, 6700 AA Wageningen, Netherlands

2 Food Quality and Design Group, Wageningen University and Research Centre, P.O. Boxs 17, 6700 AA Wageningen, Netherlands

3 Food Process Engineering, Wageningen University and Research Centre, P.O. Box 17, 6700 AA Wageningen, Netherlands

4 Division of Human Nutrition, Wageningen University and Research Centre, P.O. Box 8129, 6700 EV Wageningen, Netherlands
Keywords Quinoa · Protein · Heat processing · Denaturation $\cdot$ Digestibility $\cdot$ Extraction $\mathrm{pH}$
Abbreviations
E8 protein isolated at $\mathrm{pH} 8$
E9 protein isolated at $\mathrm{pH} 9$
E10 protein isolated at $\mathrm{pH} 10$
E11 protein isolated at $\mathrm{pH} 11$
QPI quinoa protein isolate.

\section{Introduction}

Quinoa has a balanced amino acid profile with high amounts of lysine and methionine. Sweet varieties of quinoa are more promising to provide high-quality protein in a more economic and sustainable way than the bitter quinoa varieties. More economic because saponins do not have to be removed, which saves in post-harvest processing. More sustainable because sweet varieties have been successfully adapted to North West European climates and soils, and could also be adapted to other regions in the world, making local quinoa production possible $[1,2]$.

Protein functionality is an important aspect to evaluate the potential of a new protein and give guidance for usage in applications. To avoid influences from other grain components in assessing the protein potential as a food ingredient, the protein can best be isolated from the grain for subsequent analysis. Conventionally, solvent extraction is used to isolate protein from plant material. During this process, protein properties and thus functionality can be affected [3]. Only a few studies have examined the impact of extraction conditions on functional properties of quinoa protein so far, and only our previous study has investigated properties of quinoa protein 
from sweet quinoa (saponin-free) [4-6]. The absence of saponins has been found to influence protein efficiency ratio, nitrogen solubility, emulsifying and foaming properties [3]. Next to extraction conditions, post-extraction processing can also influence protein properties. A few recent studies have investigated the effects of post-extraction heating on some properties of Quinoa Protein Isolates (QPI). We previously found that QPI suspensions started to gel at about $70^{\circ} \mathrm{C}$ when extracted at $\mathrm{pH} 8$ and 9 but no gelation was observed when extracted at $\mathrm{pH} 10$ or 11. Maekinen et al. (2015) reported that cold-set QPI gels were finer, more regularly structured and had a higher storage modulus when QPI suspensions were heat-treated $\left(100^{\circ} \mathrm{C}, 15 \mathrm{~min}\right)$ at $\mathrm{pH} 10.5$ than when heat-treated at $\mathrm{pH} 8.5$ [7]. Silva et al. (2015) found that heat treatments $\left(100{ }^{\circ} \mathrm{C}, 30 \mathrm{~min}\right)$ of quinoa protein fractions containing anti-nutritional factors increased in vitro protein digestibility. To the best of our knowledge, no studies have investigated the effect of varying heat processing parameters on protein denaturation and digestibility of QPIs. Protein denaturation and digestibility are main determinants of protein quality and would be important for application of quinoa (protein) in food products [8]. Gastric protein digestibility is a first indicator of overall protein digestibility and nutritional value of the protein $[9,10][11-13]$. Therefore, in the present study, we examined how heat processing at different temperatures influenced denaturation properties and in vitro gastric digestibility of sweet quinoa protein isolated at various extraction $\mathrm{pH}$ values. Based on literature, we hypothesize that heat processing in the temperature range of 60 to $120{ }^{\circ} \mathrm{C}$ increases in vitro gastric digestibility of the quinoa protein at mildly alkaline extraction $\mathrm{pH}$ and decreases the digestibility at strongly alkaline extraction $\mathrm{pH}$.

\section{Material and Methods}

\section{Materials}

Quinoa seeds (Chenopodium quinoa Willd) of the sweet variety Atlas were supplied by the Agricultural Research Institute (INIA) in Santiago, Chile. Petroleum ether (boiling range $40-60^{\circ} \mathrm{C}$ ) was used (Sigma-Aldrich Chemie GmbH, Schnelldorf, Germany). Chemicals for preparation of the simulated gastric juice were purchased from Sigma-Aldrich, Inc. (St. Louis, MO, U.S.A.).

\section{Preparation of Quinoa Protein Isolates}

Quinoa seeds were ground with a Fritsch Mill Pulverisette 14 (Idar-Oberstein, Germany) using a speed of $7000 \mathrm{rpm}$ and sieved through a $200 \mu \mathrm{m}$ sieve. The flour was defatted in a Soxhlet using petroleum ether with a sample-to-solvent mass ratio of 1:5 for $24 \mathrm{~h}$ [14]. The petroleum ether was removed by evaporation. The defatted flour was suspended in deionized water $(10 \% \mathrm{w} / \mathrm{w})$ and the $\mathrm{pH}$ was adjusted to $8,9,10$ and 11 by addition of $1 \mathrm{~N} \mathrm{NaOH}$. The suspensions were stirred for $1 \mathrm{~h}$ at room temperature and centrifuged for $20 \mathrm{~min}$ at $6000 \mathrm{~g}$ and $10{ }^{\circ} \mathrm{C}$. The obtained supernatants were acidified to $\mathrm{pH} 5.5$ by addition of $1 \mathrm{~N} \mathrm{HCl}$. The suspensions were centrifuged for $30 \mathrm{~min}$ at $13,000 \mathrm{~g}$ and $10^{\circ} \mathrm{C}$. The precipitated pellets were resuspended in deionized water $(5 \% \mathrm{w} / \mathrm{w})$. To rinse remaining salts the suspensions were centrifuged for $20 \mathrm{~min}$ at $11,000 \mathrm{~g}$ and $10{ }^{\circ} \mathrm{C}$, re-suspended in deionized water $(5 \% \mathrm{w} / \mathrm{w})$ and neutralized by addition of $1 \mathrm{~N} \mathrm{NaOH}$. The suspensions were frozen by dipping into liquid nitrogen and subsequently freeze-dried for $72 \mathrm{~h}$ (Chris Epsilon 2-6D Freeze Dryer, Osterode am Harz, Germany). The dried protein isolates were ground with a spoon for about $30 \mathrm{~s}$ to obtain powders. Isolates were obtained in duplicate from two separate extractions.

\section{Determination of Protein Yield and Purity}

8 to $15 \mathrm{mg}$ QPI was weighed in tin cups and dried overnight at $60{ }^{\circ} \mathrm{C}$. The nitrogen content was determined by sample combustion in a Dumas Flash EA 1112, Series NC analyzer (Wigan, UK) and converted to crude percentage of protein using a protein factor of 5.85 [4, 15, 16]. Measurements were performed in duplicate. Protein yield and protein purity were calculated as follows:

$$
\begin{aligned}
& \text { Protein yield }(\%)=\frac{\text { protein content isolate }(\%) \times \text { dry isolate }(\mathrm{g})}{\text { protein content flour }(\%) \times \text { flour }(\mathrm{g})} \times 100 \\
& \text { Protein purity }(\%)=\frac{\text { protein content isolate }(\%) \times \text { dry isolate }(\mathrm{g})}{\text { dry isolate }(\mathrm{g})} \times 100
\end{aligned}
$$

\section{Heat Processing of Quinoa Protein Isolates}

Suspensions of the QPIs obtained at the different extraction $\mathrm{pH}$ values were prepared at protein concentrations 1,5 and $20 \% \mathrm{w} /$ $\mathrm{W}$ in deionized water and stirred for $1 \mathrm{~h}$ at room temperature. For the heat processed samples, the suspensions were heattreated in an Eppendorf thermomixer (Eppendorf $\mathrm{AG}$, Hamburg, Germany) for $30 \mathrm{~min}$ at 60,90 and $120^{\circ} \mathrm{C}$ and then cooled down to room temperature. The temperatures were selected based on temperatures used in applications and to test within a wide range of temperatures. A temperature of $90{ }^{\circ} \mathrm{C}$ represents pasteurization conditions, while a temperature of $120{ }^{\circ} \mathrm{C}$ is representative for sterilization conditions. Treatment at $60{ }^{\circ} \mathrm{C}$ was chosen as mild heating temperature without causing denaturation of the quinoa protein. The terms "processing temperature of $20{ }^{\circ} \mathrm{C}$ " and "unprocessed" refer to the incubation of QPI suspensions at $20{ }^{\circ} \mathrm{C}$ without further treatment.

\section{Determination of Molecular Weight Distribution}

Sodium dodecyl sulphate-polyacrylamide gel electrophoresis (SDS-PAGE) was used to determine the molecular weight distribution of the quinoa protein isolate fractions. Heat- 
processed and unprocessed suspensions of $1 \% \mathrm{w} / \mathrm{w}$ protein concentration were prepared. The suspensions were then resuspended in deionized water $(\mathrm{pH} 6.5 \pm 0.1)$ and centrifuged for $1 \mathrm{~min}$ at $13,000 \mathrm{~g}$ to obtain the solubilized protein. The supernatants were diluted with 1 x NuPAGE ${ }^{\circledR}$ LDS Sample Buffer and deionized water before applying the samples to the gel. NuPAGE ${ }^{\circledR}$ Novex $^{\circledR}$ Bis-Tris Gels (1-200 kDa) containing $12 \%$ acrylamide (4\% acrylamide stacking gel) were used. The molecular weight markers were from NuPAGE ${ }^{\circledR}$ Novex ${ }^{\circledR}$ (Mark 12 ${ }^{\mathrm{TM}}$ Unstained Standard, 2.5-200 kDa). Protein bands were stained with Simply Blue ${ }^{\text {TM }}$ SafeStain.

\section{Determination of Thermal Properties}

The thermal properties of the QPIs were assessed by Differential Scanning Calorimetry (DSC). Heat-processed and unprocessed suspensions of $20 \% \mathrm{w} / \mathrm{w}$ protein concentration were prepared. Hermetically sealed aluminum pans were filled with 25-50 $\mathrm{mg}$ of heat-processed or unprocessed QPI suspensions. DSC samples were heated at a rate of $10^{\circ} \mathrm{C} / \mathrm{min}$ from 20 to $140{ }^{\circ} \mathrm{C}$ using a PerkinElmer Diamond series differential scanning calorimeter equipped with an intracooler 2P. A double, empty pan was used as reference. The denaturation parameters were calculated using Pyris Software (Version 11, PerkinElmer) with the denaturation temperature $\left(T_{d}\right)$ value corresponding to the maximum transition peak and the transition enthalpy (denaturation enthalpy $\Delta \mathrm{H}$ ) calculated from the area below the transition peaks. Measurements were performed in duplicate for isolates obtained in duplicate.

\section{Determination of in Vitro Gastric Protein Digestibility}

Simulated gastric juice was prepared according to $[17,18]$. Pepsin (1 g L-1), mucin (1.5 g L-1), and $\mathrm{NaCl}$ (8.775 g L-1) were dissolved in Milli-Q water and the $\mathrm{pH}$ was adjusted to 2.0 with $2 \mathrm{M} \mathrm{HCl}$. Heat-processed and unprocessed QPI suspensions, as well as suspensions of whole meal quinoa flour ( $5 \% \mathrm{w} / \mathrm{w}$ protein, $2 \mathrm{~mL}$ ), were prepared and added to $50 \mathrm{~mL}$ of simulated gastric juice in a jacketed glass vessel connected to a water bath at $37^{\circ} \mathrm{C}$ (Julabo GmbH, Seelbach, Germany). The vessel was sealed with Parafilm (Pechiney Plastic Packaging, Inc., IL, U.S.A.) to avoid evaporation and the gastric juice solutions were stirred at $100 \mathrm{rpm}$. Samples of $1 \mathrm{~mL}$ were taken after $0,5,10,15,20,30,45,60,90,120,150,180$, 240 and $360 \mathrm{~min}$ and heated under stirring in a pre-heated Eppendorf thermomixer (Eppendorf AG, Hamburg, Germany) at $90{ }^{\circ} \mathrm{C}$ and $1400 \mathrm{rpm}$ for $5 \mathrm{~min}$ to inactivate pepsin [19]. All measurements were performed in triplicate.

\section{Determination of Degree of Hydrolysis (DH)}

The degree of hydrolysis (DH) is defined as the percentage of cleaved peptide bonds over the total number of peptide bonds. The latter was calculated as follows:

Total number of peptide bonds $=\frac{\text { average molecular weight of amino acids }(\mathrm{kDa})}{1000 \mathrm{~g} \text { protein }}$

To estimate DH, the OPA method was used as described by Luo et al. (2015). The OPA reagent was prepared and stored in a bottle covered with aluminum foil to protect the reagent from light. A spectrophotometer DU 720 (Beckman Coulter Inc. Pasadena, CA, U.S.A) was set at $340 \mathrm{~nm}$ with $1.5 \mathrm{~mL}$ OPA reagent $+0.2 \mathrm{~mL}$ Milli-Q water. Serine standard solutions of $200 \mu \mathrm{L}$ of $50 \mathrm{mg} / \mathrm{L}, 100 \mathrm{mg} / \mathrm{L}, 150 \mathrm{mg} / \mathrm{L}$ and $200 \mathrm{mg} / \mathrm{L}$ were added to $1.5 \mathrm{~mL}$ OPA reagent and mixed. The solutions were measured with the spectrophotometer after standing for $3 \mathrm{~min}$. The samples were pipetted into the Amicon Ultra-0.5 $10 \mathrm{~K}$ Centrifugal Filter Units (Millipore, USA) and centrifuged for $20 \mathrm{~min}$ at 14,000 g. All measurements were performed in triplicate.

\section{Size Exclusion Chromatography (SEC)}

The peptide profile after digestion was analyzed using SEC Ultimate 3000 UHPLC system (Thermo Scientific, MA, U.S.A.) equipped with a TSKgel G2000SWxl column (Tosoh Bioscience LLC, PA, U.S.A.). $0.1 \mathrm{~mL}$ sample was used for analysis. The running buffer consisted of acetonitrile and $70 \%$ Milli-Q water with $0.1 \%$ Trifluoro Acetic Acid (TFA). The flow rate of the running buffer was $1 \mathrm{~mL} / \mathrm{min}$ and the UV detector was set at $214 \mathrm{~nm}$. In order to standardize the molecular weight range of the chromatographic separation, the following purified proteins and amino acids were used for calibration: carbonic anhydrase (29 kDa), $\alpha$ lactalbumin $(14.1 \mathrm{kDa})$, aprotinin $(6.51 \mathrm{kDa})$, insulin (5.7 kDa), bacitracin $(1.42 \mathrm{kDa})$ and phenylalanine (165 Da) (Sigma-Aldrich, Inc., St. Louis, MO, U.S.A.). The area under the curves was determined and the relative area for each segment calculated. All measurements were done in triplicate.

\section{Results and Discussion}

\section{Protein Yield and Purity}

When extracting quinoa protein in a $\mathrm{pH}$ range of $8-11$, a protein purity of 90-93\% was obtained (Fig. 1). These values 
are the highest reported in literature so far [4, 6, 20-23]. In our previous study, we used a similar extraction protocol, only the alkalinization time was longer and the precipitation $\mathrm{pH}$ lower, resulting in a lower protein purity (82-88 \%) [20]. Protein yield increased from 24 to $37 \%$ when increasing the extraction $\mathrm{pH}$ from 8 to 11 . These values are lower than in our previous study (35-50 \% going from extraction $\mathrm{pH} 8$ to 11) but they also increased with extraction $\mathrm{pH}$. For industrial production of quinoa protein isolates, this means that the extraction $\mathrm{pH}$ would need to be controlled carefully.

\section{Thermal Properties}

Unprocessed and processed $20 \%$ QPI suspensions showed an endotherm from 96 to $102{ }^{\circ} \mathrm{C}$ (denaturation temperature range) (Figs. 8, 9, 10,11, 12), which is in line with denaturation temperatures $\left(T_{d}\right)$ previously found for quinoa, amaranth and sunflower protein. These denaturation temperatures have been attributed to $11 \mathrm{~S}$ globulin $[4,16,20,24,25]$. Therefore, we assume that the endotherm found in our study also mainly corresponds to 11S globulin. There was no significant change in $T_{d}$ with processing temperature, but $\mathrm{T}_{\mathrm{d}}$ decreased with increasing extraction $\mathrm{pH}$. This decrease was also observed by Martínez \& Añón (1996) for amaranth protein and indicates that protein is less heat-stable when extracted at higher $\mathrm{pH}$ [24].

The denaturation enthalpy of the unprocessed QPI suspensions decreased considerably from 13.5 to $3.8 \mathrm{~J} / \mathrm{g}$ protein with increasing extraction $\mathrm{pH}$ (Fig. 2). This trend has also been observed in several other studies on quinoa, amaranth and sunflower protein, showing that the protein is more denatured at higher extraction $\mathrm{pH}[4,16,20,24,25]$. When QPI suspensions were processed at 90 and $120{ }^{\circ} \mathrm{C}$, the denaturation enthalpy was reduced to $0-3.4 \mathrm{~J} / \mathrm{g}$ protein. However, the enthalpy was significantly higher after processing at $60{ }^{\circ} \mathrm{C}$ than at $20^{\circ} \mathrm{C}$ for E9, E10 and E11.

Martínez \& Añón (1996) have summarized the notion of denaturation enthalpy to be the result of endothermal processes, e.g. disruption of hydrogen bonds, and exothermal processes, e.g. protein aggregation and disruption of hydrophobic interactions. The higher denaturation enthalpy (or transition enthalpy) of E9, E10 and E11 at $60{ }^{\circ} \mathrm{C}$ might thus indicate a conformation of the protein that was stabilized by a greater extent of hydrophobic interactions and/or hydrogen bonds and that cost more transition energy than at 20,90 or $120^{\circ} \mathrm{C}$. The exception was E8, which showed a continuous decrease in enthalpy from 20 to $120^{\circ} \mathrm{C}$. Based on the notion of denaturation enthalpy of Martínez \& Añón (1996) it might be that at an extraction $\mathrm{pH}$ of 8 the protein initially contained a higher degree of hydrophobic interactions and/or hydrogen bonds as compared to the protein obtained at other extraction $\mathrm{pH}$ values. These molecular interactions might have decreased in number from a processing temperature of 20 to $60{ }^{\circ} \mathrm{C}$ in contrast to the other extraction $\mathrm{pH}$ values, where the protein initially had undergone more extensive conformational changes due stronger alkaline extraction conditions, resulting in a different degree of molecular interactions after processing at $60{ }^{\circ} \mathrm{C}$. In summary, the effect of processing temperature on the thermal properties of QPIs seemed to depend on the protein properties predetermined by the extraction $\mathrm{pH}$.

\section{Protein Fractions}

SDS profiles showed major bands at $50 \mathrm{kDa}$ for all QPIs and at $37 \mathrm{kDa}$ for E8, E9 and E10 (Fig. 3). The bands of E8 were the most intense and decreased in intensity with increasing extraction $\mathrm{pH}$. The SDS profiles were similar to the ones of previous quinoa protein studies, suggesting a correspondence of the bands at $50 \mathrm{kDa}$ to $11 \mathrm{~S}$ globulin $[4,20,26]$. Furthermore, bands at $37 \mathrm{kDa}$ might correspond to the acidic subunit and bands at $23 \mathrm{kDa}$ might be attributed to the basic subunit of 11S globulin. Alkali is known to cause disulfide bond cleavage, resulting in the dissociation of $11 \mathrm{~S}$ globulin into acidic and basic subunits of 32-39 kDa and 22-23 kDa, respectively [27].
Fig. 1 Protein yield and protein purity on dry matter basis of the quinoa protein isolates E8, E9, E10 and E11. Error bars represent the standard deviation based on duplicate extraction experiments

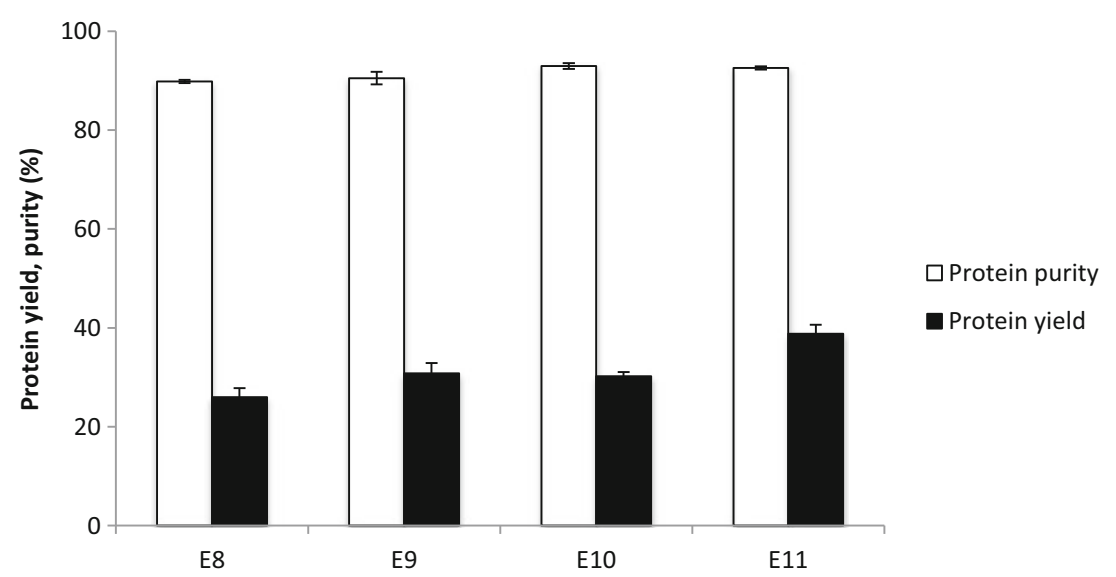


Fig. 2 a Denaturation temperature $\left(\mathrm{T}_{\mathrm{d}}\right)$ and $\mathbf{b}$ denaturation enthalpy $(\Delta \mathrm{H})$ of $20 \% w / w$ suspensions of QPI E8, E9, E10 and E11 after processing at different temperatures. Data were obtained from DSC measurements a

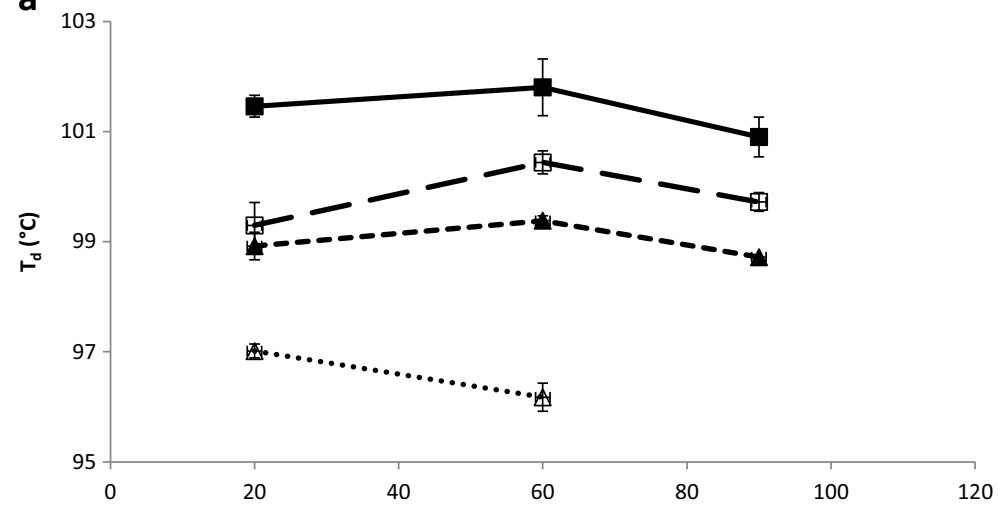

b

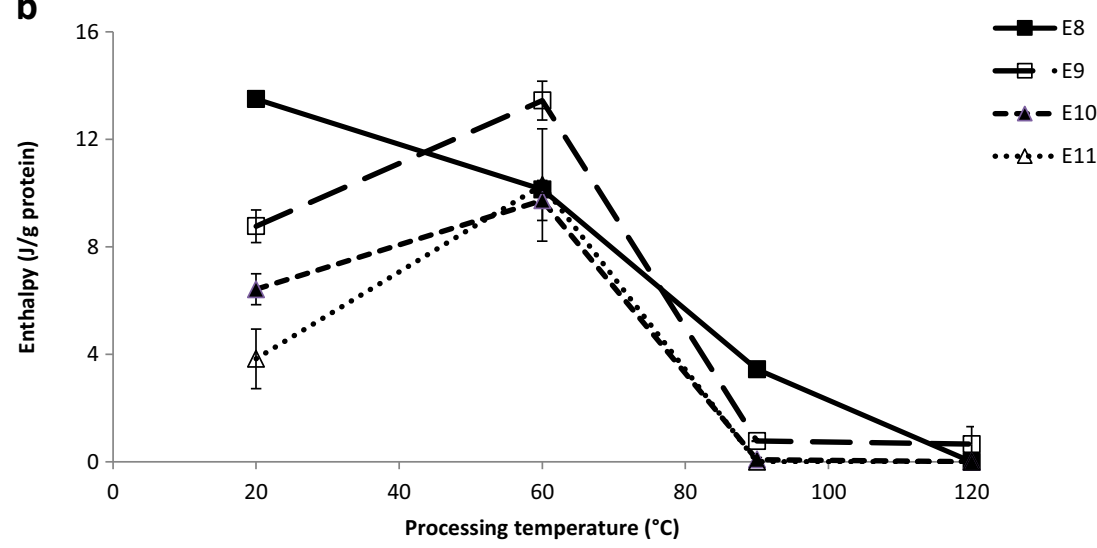

After heat processing, the SDS profiles showed less bands with less intensity for all QPIs (Fig. 4). In some lanes specific bands were even not visible anymore.

The disappearance of bands with increasing processing temperature indicates enhanced protein aggregation to protein particles larger than $200 \mathrm{kDa}$ or to insoluble protein particles that remained in the pellet after centrifuging the heatprocessed protein suspensions. Protein aggregation might have resulted from increased protein dissociation and subunit interactions and re-association to larger (insoluble) aggregates as reported for heat-processed soy protein (0-30 min at 80 and $\left.100{ }^{\circ} \mathrm{C}\right)[28,29]$. DSC results showed higher denaturation enthalpies of the unprocessed and $60{ }^{\circ} \mathrm{C}$-processed QPI suspensions compared to the suspensions processed at 90 and $120^{\circ} \mathrm{C}$. As described before, the higher enthalpies might result from more hydrophobic interactions, hydrogen bonds but also from increased protein aggregation, according to Martínez \& Añón (1996). Based on the results of SDS and DSC, it seems likely that protein aggregation leads to insoluble particles remaining in the pellet, especially at $120{ }^{\circ} \mathrm{C}$ (less protein on the SDS gels), while the aggregates seem to be less capable to undergo a heat-induced phase transition up to a temperature of $140{ }^{\circ} \mathrm{C}$ (maximum temperature reached during DSC measurements) compared to protein treated at $60{ }^{\circ} \mathrm{C}$.

\section{In Vitro Gastric Protein Digestibility of Quinoa Protein Isolates}

Gastric digestibility of the QPIs was studied in vitro simulating physiological conditions and was indicated as the degree of protein hydrolysis (\% peptide bonds cleaved by pepsin of total bonds). The degree of hydrolysis (DH) of unprocessed and processed $5 \%$ QPI suspensions sharply increased within the first $20 \mathrm{~min}$ and further increased at a slower rate in the following hours (Fig. 5). The hydrolysis profiles compare to those of whey protein and egg white protein obtained by Luo et al. (2015) at the same protein concentration, and under the same digestion and measurement conditions. When interpolating the DH values of the QPI suspensions treated at $90{ }^{\circ} \mathrm{C}$ to a digestion time of $3 \mathrm{~h}$, the $\mathrm{DH}$ of quinoa protein was slightly lower (13-14\%) than the DH of whey protein (15\%) but higher than the $\mathrm{DH}$ of egg white protein $(11 \%)$, both pretreated for $30 \mathrm{~min}$ at $90{ }^{\circ} \mathrm{C}$ and digested for $3 \mathrm{~h}$.

HPLC chromatograms showed that when digesting unprocessed and processed QPI suspensions for 5-360 min higher amounts of peptides ranging from 0.5 to $5 \mathrm{kDa}$ were obtained (Figs. 6, 14, 15, 16). The peaks in the molecular size range of $0.5-5 \mathrm{kDa}$ became larger and moved to a smaller size range with increasing in vitro digestion time. As digestion progressed, pepsin cleaved increasingly more peptide bonds, 




Fig. 3 SDS-PAGE profile of the unprocessed QPIs E8, E9, E10 and E11. Lane M: molecular weight marker

resulting in smaller molecules. When comparing processing temperatures, the chromatograms did not significantly change from 20 to $60{ }^{\circ} \mathrm{C}$. However, at 90 and $120^{\circ} \mathrm{C}$, the response areas were significantly smaller compared to 20 and $60{ }^{\circ} \mathrm{C}$. This is most clearly visible after 5 and $20 \mathrm{~min}$ of digestion. This finding could be confirmed by DH measurements (Fig. 5): the $\mathrm{DH}$ was reduced overall at 90 and $120^{\circ} \mathrm{C}$ compared to 20 and $60{ }^{\circ} \mathrm{C}$. Similar observations were made for lupine protein [30]. A heat treatment at $60{ }^{\circ} \mathrm{C}$ for $30 \mathrm{~min}$ did not change the digestibility of lupine protein compared to the untreated sample, while a heat treatment at $90^{\circ} \mathrm{C}$ for $30 \mathrm{~min}$ did reduce the digestibility. The reduction in the $\mathrm{DH}$ at higher processing temperature was enhanced at higher extraction $\mathrm{pH}$.

These results suggest that pepsin was less effective after heat-treatment of the QPI suspensions. This might be explained by the heat-induced change in protein conformation, molecular interactions and protein aggregation as indicated by DSC and SDS results. Increased protein aggregation after the heat treatments might have reduced the accessibility of pepsin. Impairment of protein digestibility for pepsin has already been previously correlated with stronger protein crosslinking when cooking sorghum [31]. The in vitro digestibility of sorghum protein using pepsin has therefore been validated as an indicator for the degree of protein crosslinking. This relation might also be valid for quinoa protein.

If this is the case, the fact that the reduction in the DH at higher processing temperature was enhanced at higher extraction $\mathrm{pH}$ can be explained with increased protein crosslinking. This might also be deduced from SDS results: with an increasing extraction $\mathrm{pH}$ and processing temperature, the degree of protein aggregation, possibly as a result of protein crosslinking, seemed to be higher. However, DSC results implied that the protein suspensions from a high extraction $\mathrm{pH}$ (10 and 11 ) and processing temperature $\left(90\right.$ and $120^{\circ} \mathrm{C}$ ) were only slightly capable or not capable at all to undergo a heatinduced phase transition. Therefore, not a greater extent of protein aggregation or crosslinking seemed to be impairing enzyme action more under these harsher conditions, but a more heat-resistant type of protein aggregation or crosslinking.

The extraction $\mathrm{pH}$ had almost no influence on the $\mathrm{DH}$ when comparing $\mathrm{pH}$ values of the unprocessed suspensions and of the processed suspensions at 60 and $90{ }^{\circ} \mathrm{C}$ (Fig. 5). This means that the effects of extraction $\mathrm{pH}$ observed on the physical properties of unprocessed QPIs and processed QPIs at 60 and $90{ }^{\circ} \mathrm{C}$ were not clearly transferred to in vitro gastric
Fig. 4 SDS-PAGE profile of the QPIs E8, E9, E10 and E11 heattreated for $30 \mathrm{~min}$ at 60,90 and $120^{\circ} \mathrm{C}$. Lane M: molecular weight marker. The gel of E10 seems to be overloaded at the bottom. E10 was run on a different gel and is shown in Fig. 13





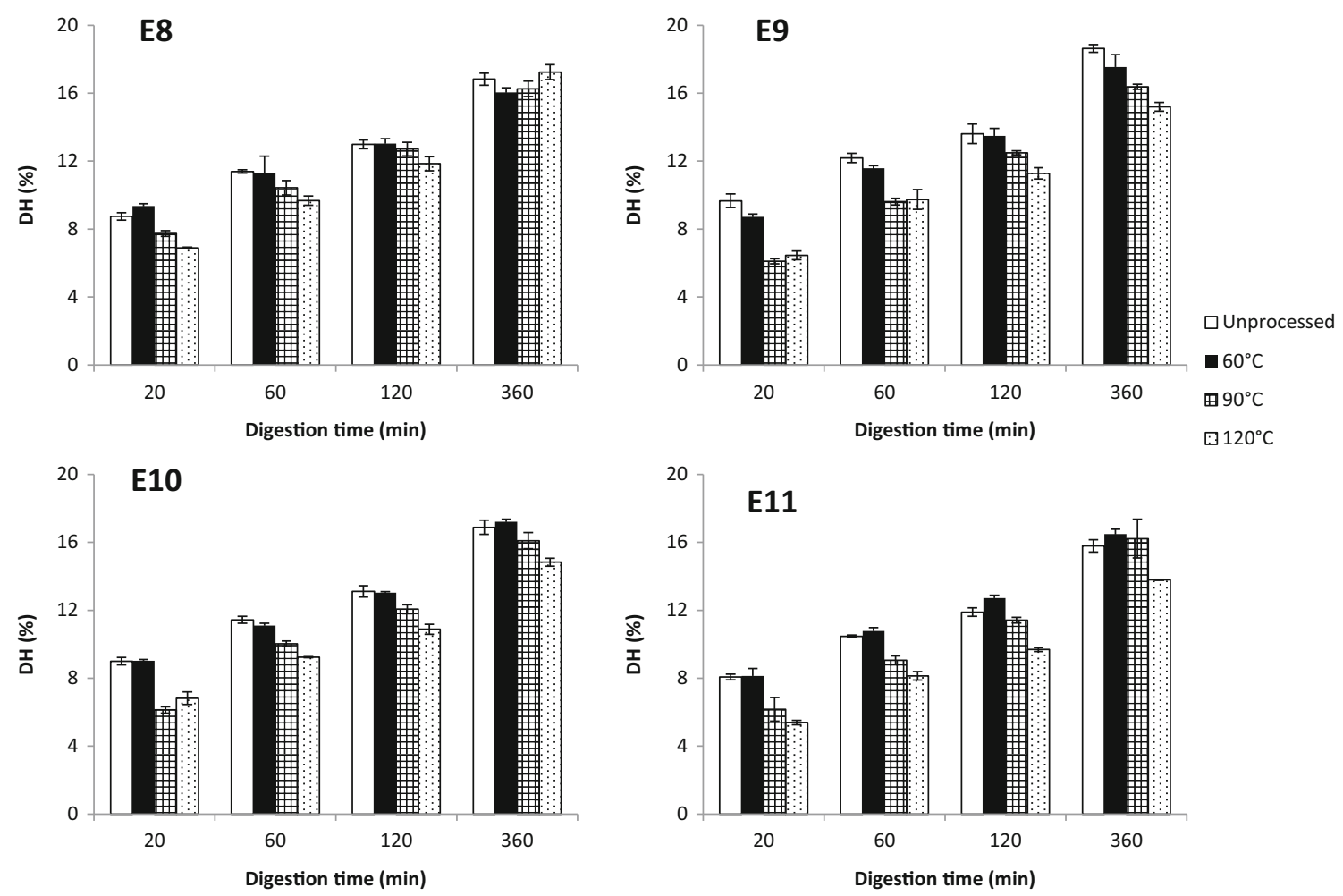

Fig. 5 Degree of hydrolysis (DH) of $5 \%$ w/w suspensions of QPI E8, E9, E10 and E11 processed at different temperatures and subsequently digested for different time periods



Fig. 6 HPLC chromatograms of $5 \% w / w$ suspensions of QPI E9 processed at different temperatures and subsequently digested for different time periods. Size exclusion chromatography is used for

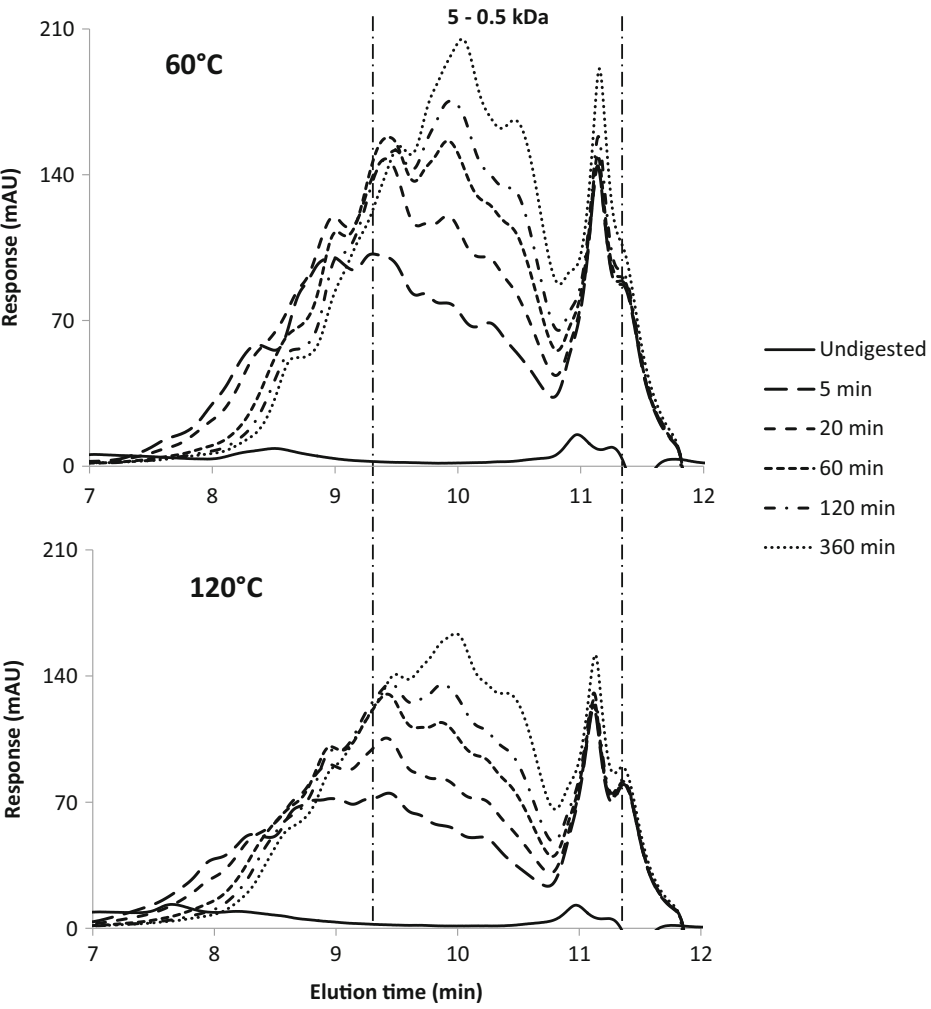

separation. This means that larger peptides have a low elution time. See Fig. 14, 15, 16 for the HPLC chromatograms of E8, E10 and E11 
digestibility. At $120{ }^{\circ} \mathrm{C}$, the rate of $\mathrm{DH}$ was only slightly reduced at extraction $\mathrm{pH} 11$ compared to the other extraction $\mathrm{pH}$ values. These results show a bigger impact of processing temperature on the DH of quinoa protein compared to extraction $\mathrm{pH}$.

We conclude that heat treatment for $30 \mathrm{~min}$ at 90 and $120^{\circ} \mathrm{C}$ impairs in vitro gastric digestibility of protein in QPIs.

\section{Gastric in Vitro Protein Digestibility of Whole Quinoa Flour}

To examine how protein digestibility in QPIs compares to that in whole quinoa flour, we performed the digestibility study with wholemeal quinoa flour at the same protein concentration. The $\mathrm{DH}$ values also increased in time and looked similar to that of the QPIs. However, the $\mathrm{DH}$ values were overall lower, especially at $120{ }^{\circ} \mathrm{C}$ (Fig. 7). This reduction in $\mathrm{DH}$ might be due to the other components present (in higher amounts) in the quinoa flour (mainly starch, fiber and fat). The mere presence of much higher amounts of starch and fiber in the quinoa flour compared to the QPIs might be the responsible factor, but also the behavior of these components at the different processing temperatures might have had an impact on digestibility [32]. The gelatinization of quinoa starch starts from 45 to $54{ }^{\circ} \mathrm{C}$, peaks from 51 to $62{ }^{\circ} \mathrm{C}$ and concludes from 64 to $71{ }^{\circ} \mathrm{C}$ [33]. At processing temperatures of 60 and $90{ }^{\circ} \mathrm{C}$, there was no large difference in the decrease in DH compared to the protein isolates, indicating that gelatinization did not affect protein digestibility significantly. There was a larger drop in $\mathrm{DH}$ from 90 to $120{ }^{\circ} \mathrm{C}$ for the quinoa flour compared to the protein isolates. As starch gelatinization did not seem to have an impact on digestibility at lower temperatures, it is possible that at higher temperatures the gelatinized starch interacted with denatured protein $\left(T_{d}=96-102{ }^{\circ} \mathrm{C}\right)$, thereby hindering enzyme action. Another explanation might be that in contrast to the protein in the flour, the protein in the protein isolates underwent conformational changes during the extraction, which limited the effect of processing temperature on protein digestibility.

\section{Conclusions}

Using the extraction protocol from the present study, we could achieve a very high protein purity, but at the expense of a low protein yield. The degree of denaturation and molecular weight profiles of the QPIs were strongly affected by processing temperature and extraction $\mathrm{pH}$, individually and combined. For QPI's, extraction $\mathrm{pH}$ and processing temperature showed an interactive effect on in vitro gastric digestibility of the protein. Extracting protein from quinoa flour results in a higher protein digestibility when compared to keeping the protein in the flour. For applications, the present findings mean that extraction and processing conditions need to be controlled to optimize protein digestibility. Future research

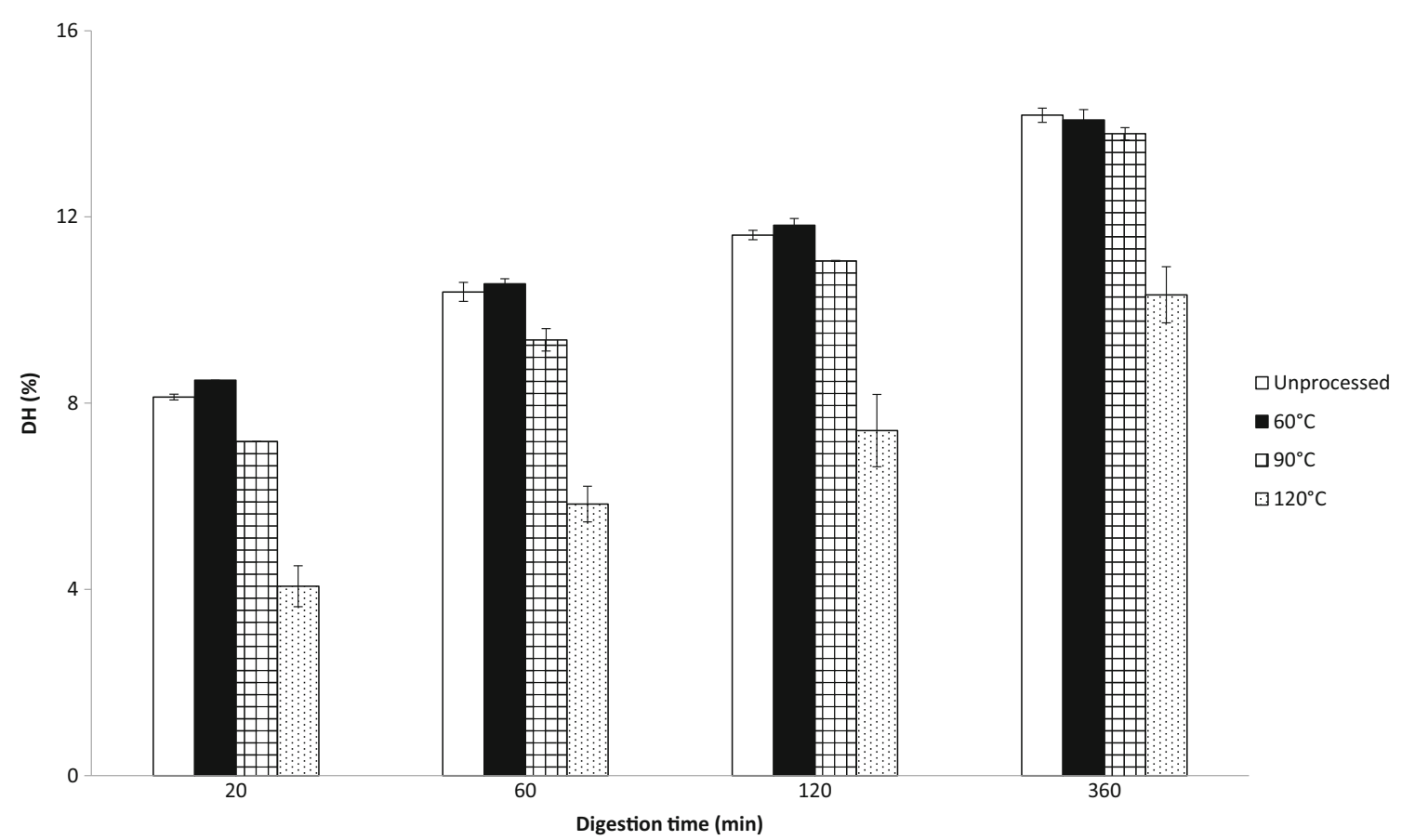

Fig. 7 Degree of hydrolysis (DH) of wholemeal quinoa flour (5\% w/w protein) processed at different temperatures and subsequently digested for different time periods 
could investigate other functional properties of quinoa protein but also examine ileal and in vivo protein digestibility under various conditions to verify the present findings in more reallife digestion conditions.

Acknowledgments Mauricio Opazo Navarrete was financially supported by a PhD scholarship of CONICYT (Formation of Advanced Human Capital Program), Chile. The authors gratefully acknowledge the financial support of the "IPOP Customized Nutrition" program of Wageningen University and Research Centre.

\section{Compliance with Ethical Standards}

Conflict of Interest The authors declare that they have no conflict of interest.

Open Access This article is distributed under the terms of the Creative Commons Attribution 4.0 International License (http:// creativecommons.org/licenses/by/4.0/), which permits unrestricted use, distribution, and reproduction in any medium, provided you give appropriate credit to the original author(s) and the source, provide a link to the Creative Commons license, and indicate if changes were made.

\section{Appendix}

Fig. 8 DSC thermograms of untreated $20 \% \mathrm{w} / \mathrm{w}$ suspensions of QPI E8, E9, E10 and E11

Fig. 9 DSC thermograms of $20 \% \mathrm{w} / \mathrm{w}$ suspensions of QPI E8 after processing at different temperatures

Fig. 10 DSC thermograms of after processing at different temperatures $20 \% \mathrm{w} / \mathrm{w}$ suspensions of QPI E9

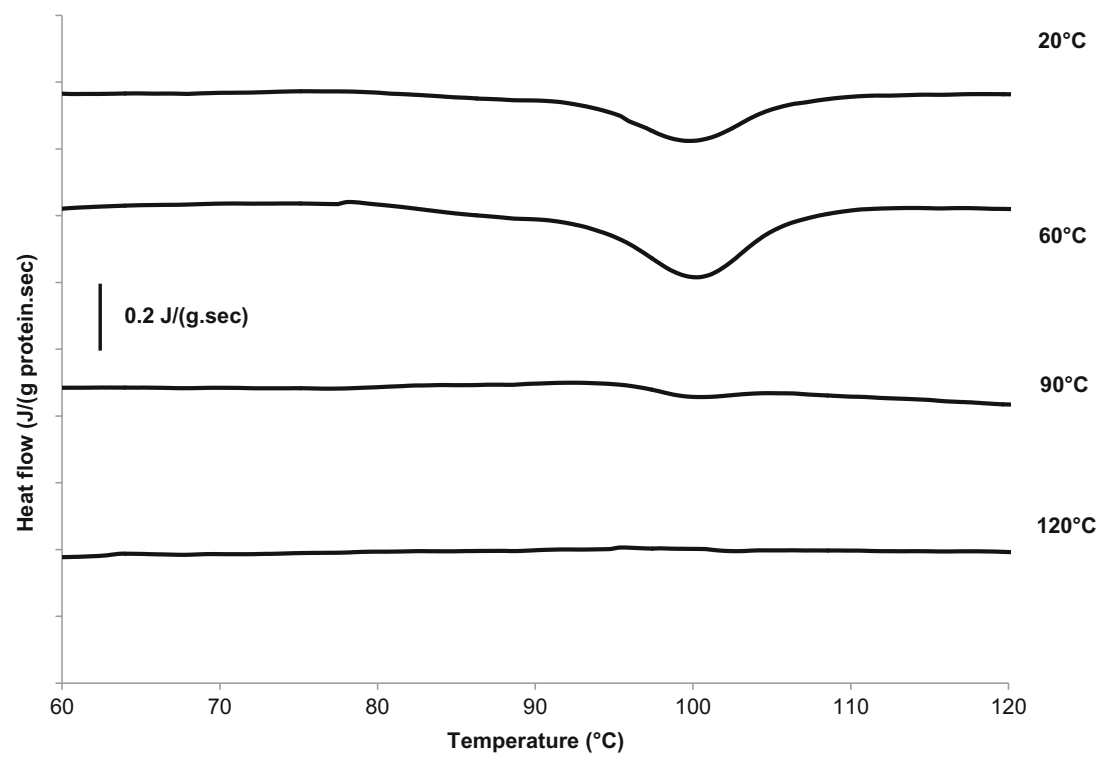

Fig. 11 DSC thermograms of $20 \% \mathrm{w} / \mathrm{w}$ suspensions of QPI E10 after processing at different temperatures

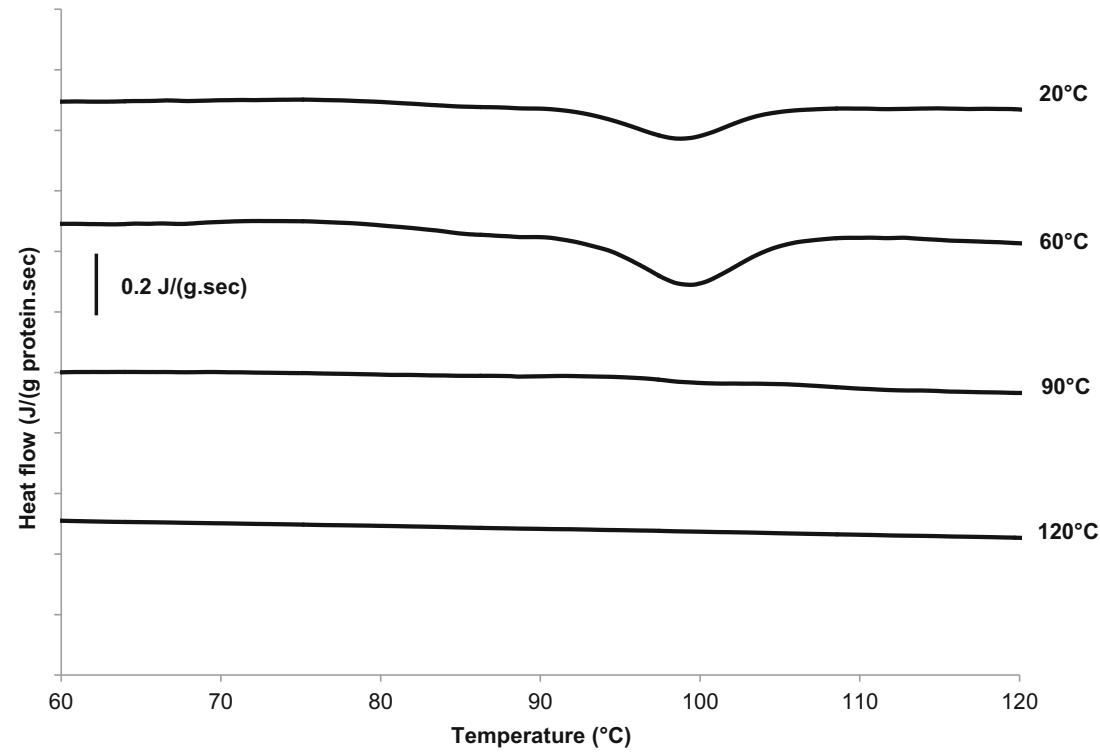


Fig. 12 DSC thermograms of $20 \% w / w$ suspensions of QPI E11 after processing at different temperatures

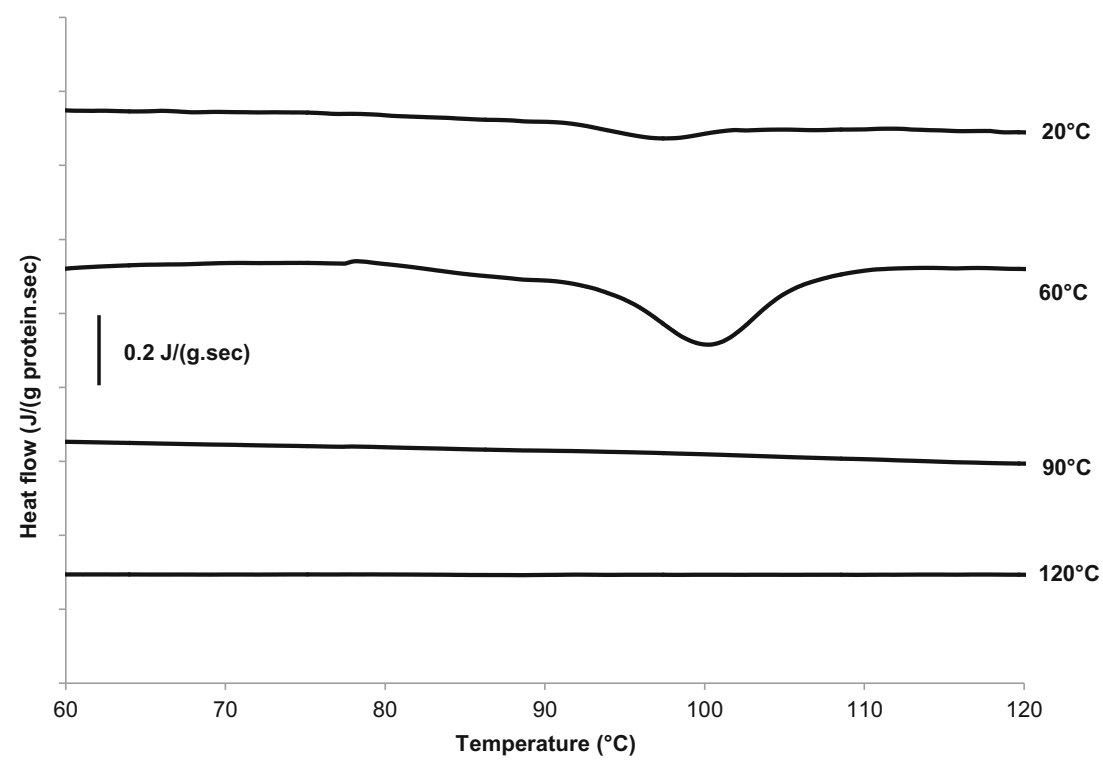

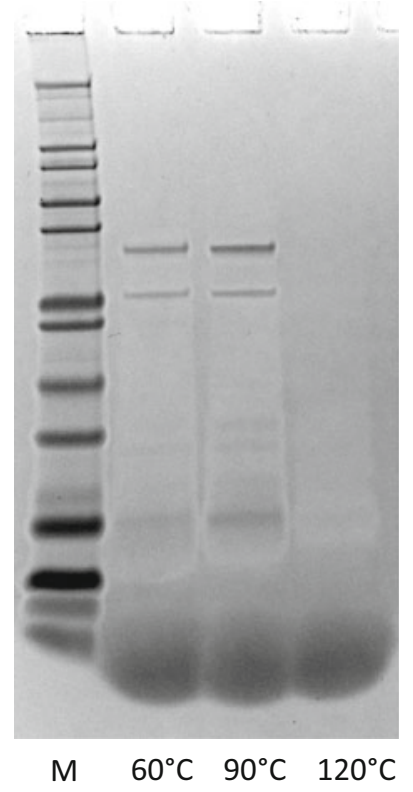

Fig. 13 SDS-PAGE profile of the QPIs E10 heat-treated for $30 \mathrm{~min}$ at 60, 90 and $120^{\circ} \mathrm{C}$. Lane M: molecular weight marker 

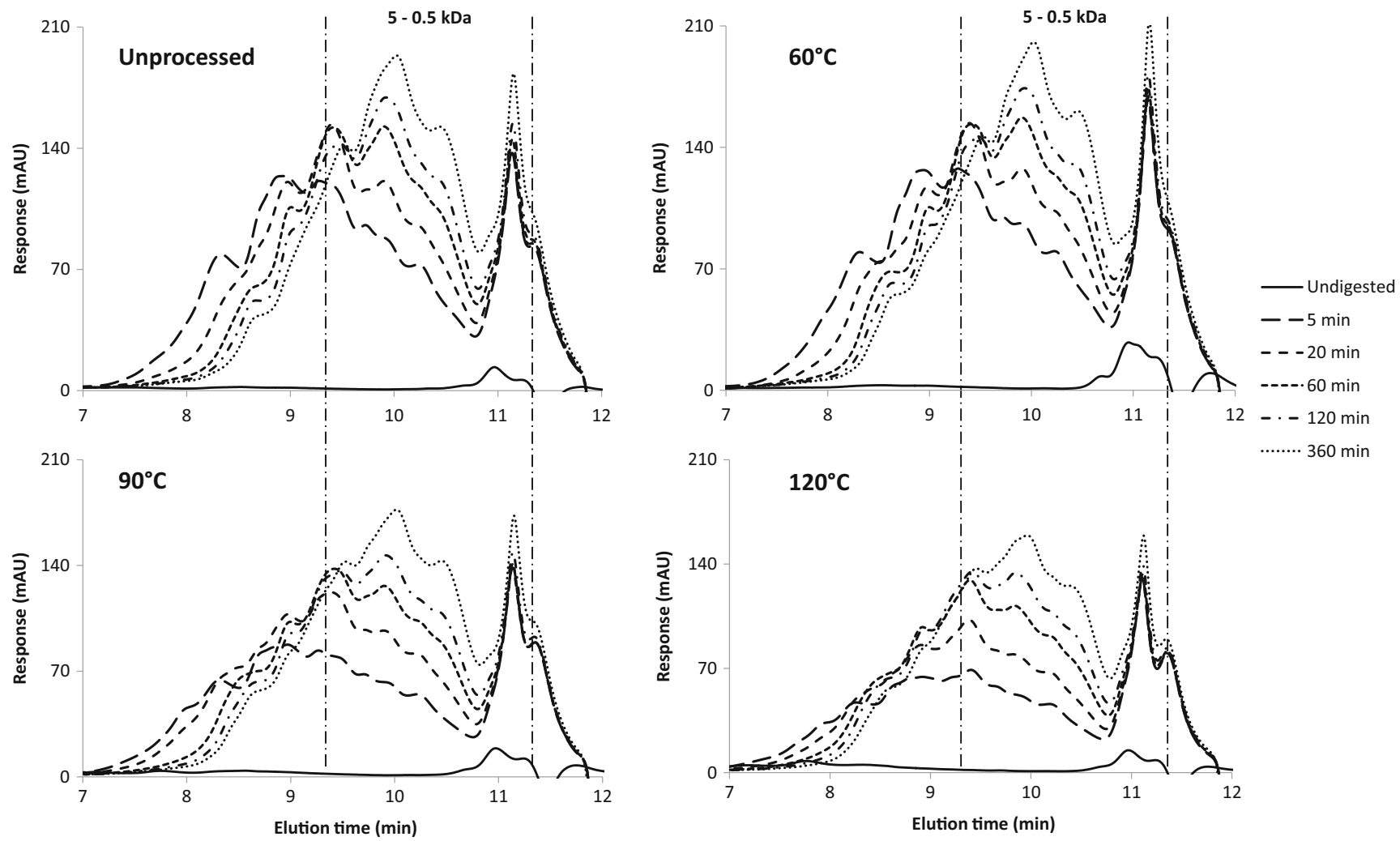

Fig. 14 HPLC chromatograms of $5 \% \mathrm{w} / \mathrm{w}$ suspensions of QPI E8 processed at different temperatures and subsequently digested for different time periods. Size exclusion chromatography is used for separation. This means that larger peptides have a low elution time
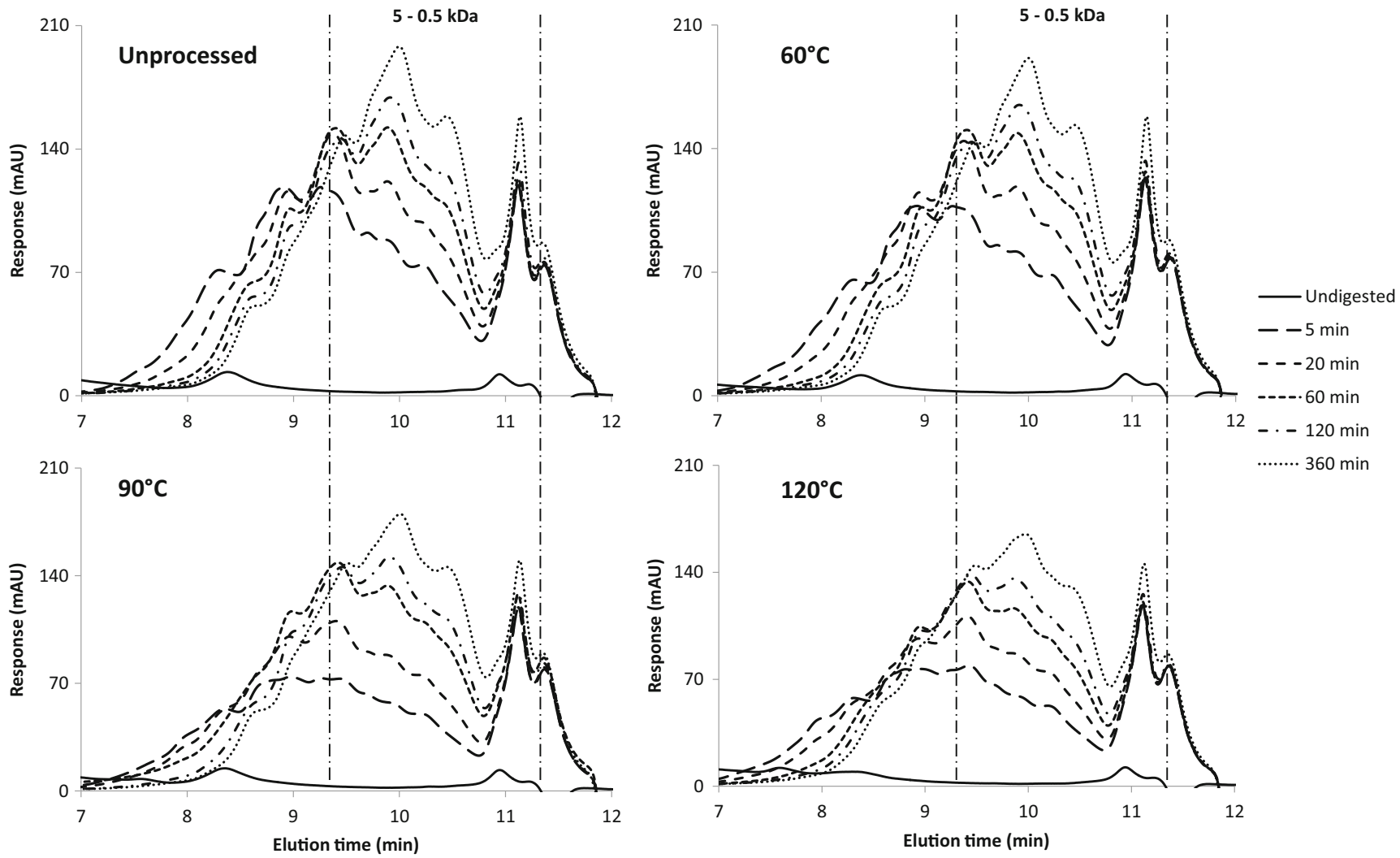

Fig. 15 HPLC chromatograms of $5 \% w / w$ suspensions of QPI E10 processed at different temperatures and subsequently digested for different time periods. Size exclusion chromatography is used for separation. This means that larger peptides have a low elution time 

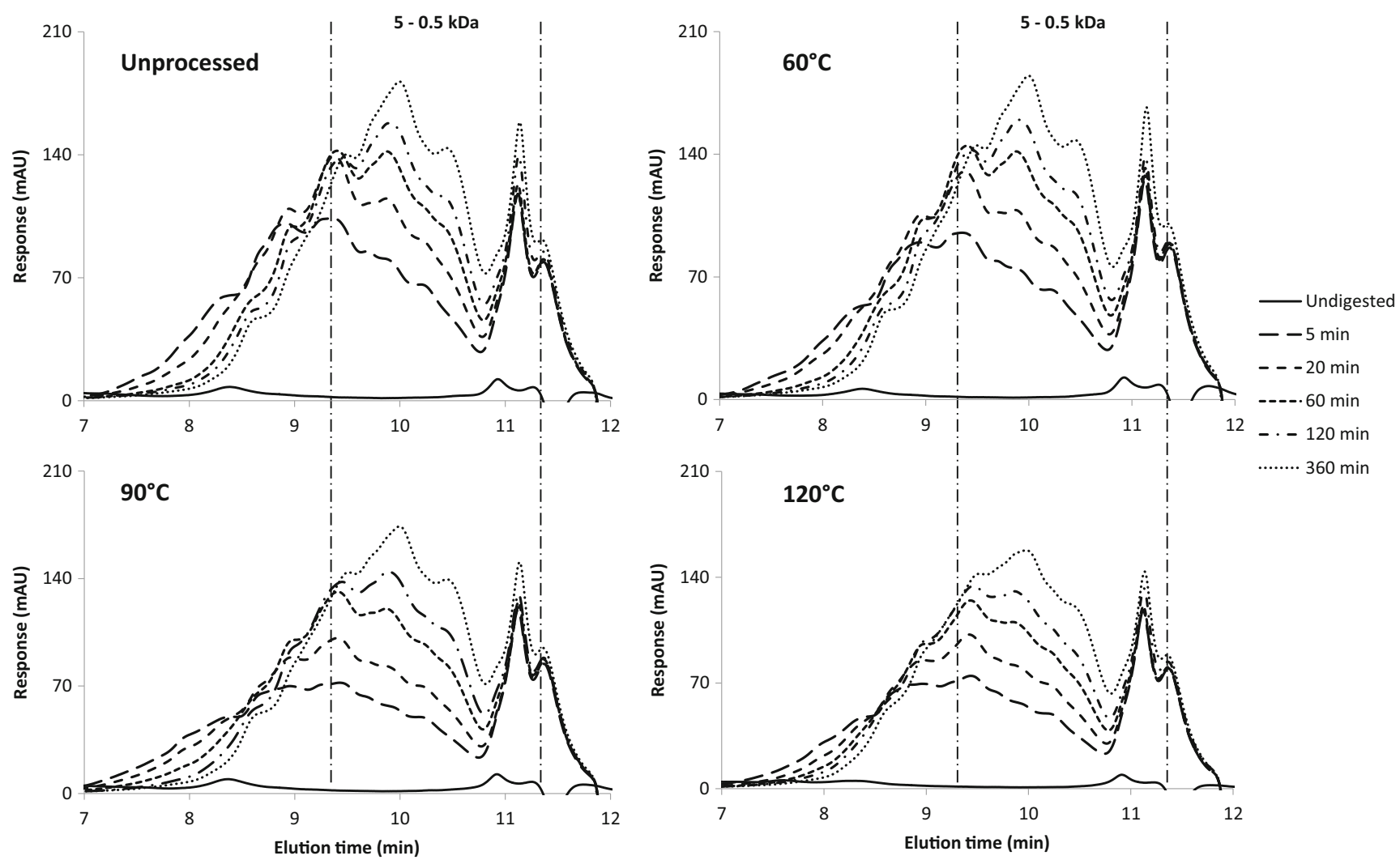

Fig. 16 HPLC chromatograms of $5 \% w / w$ suspensions of QPI E11 processed at different temperatures and subsequently digested for different time periods. Size exclusion chromatography is used for separation. This means that larger peptides have a low elution time

\section{References}

1. Limburg H, Masterbroek HD Breeding high yielding lines of Chenopodium quinoa Willd. with saponin free seed. In: Stølen O, Bruhn K, Pithan K, Hill J (eds) Proc COST 814 workshop on Small Grain Cereals and Pseudo-Cereals, Copenhagen, 24 February 1997. pp 103-114

2. H. D. Mastebroek, E. N. van Loo, O. Dolstra, Combining ability for seed yield traits of Chenopodium quinoa breeding lines. Euphytica 125(3), 427-432 (2002). doi:10.1023/a:1016030129541

3. Avila Ruiz G, Xiao W, van Boekel M, Stieger M, Minor M (2016) Effect of extraction $\mathrm{pH}$ on heat-induced aggregation, gelation and microstructure of protein from sweet quinoa (Chenopodium quinoa Willd) (submitted)

4. L. E. Abugoch, N. Romero, C. A. Tapia, J. Silva, M. Rivera, Study of some physicochemical and functional properties of quinoa (Chenopodium quinoa willd) protein isolates. J. Agric. Food Chem. 56(12), 4745-4750 (2008). doi:10.1021/jf703689u

5. C. Valenzuela, L. Abugoch, C. Tapia, A. Gamboa, Effect of alkaline extraction on the structure of the protein of quinoa (Chenopodium quinoa willd.) and its influence on film formation. Int J Food Sci Tech 48(4), 843-849 (2013). doi:10. 1111/ijfs. 12035

6. J. C. C. Aora, K. Alvarado, Aislados proteínicos de granos altoandinos chenopodiaceas; quinua Chenopodium quinoa cañahua Chenopodium pallidicaule por precipitación isoeléctrica. Revista Boliviana de Química 26(1), 12-20 (2009)

7. O. Mäkinen, E. Zannini, E. Arendt, Modifying the cold gelation properties of quinoa protein isolate: influence of heat-denaturation $\mathrm{pH}$ in the alkaline range. Plant Foods Hum. Nutr., 1-7 (2015). doi: 10.1007/s11130-015-0487-4
8. X. Guo, H. Yao, Z. Chen, Effect of heat, rutin and disulfide bond reduction on in vitro pepsin digestibility of Chinese tartary buckwheat protein fractions. Food Chem. 102(1), 118-122 (2007). doi: 10.1016/j.foodchem.2006.04.039

9. H. Mokrane, H. Amoura, N. Belhaneche-Bensemra, C. M. Courtin, J. A. Delcour, B. Nadjemi, Assessment of Algerian sorghum protein quality [Sorghum bicolor (L.) Moench] using amino acid analysis and in vitro pepsin digestibility. Food Chem. 121(3), 719-723 (2010). doi:10.1016/j.foodchem.2010.01.020

10. A. K. Sarker, D. Saha, H. Begum, A. Zaman, M. M. Rahman, Comparison of cake compositions, pepsin digestibility and amino acids concentration of proteins isolated from black mustard and yellow mustard cakes. AMB Express 5, 22 (2015). doi:10.1186/ s13568-015-0110-y

11. G. Budryn, E. Nebesny, D. Rachwał, Pepsin digestibility and antioxidant activity of egg white protein in model systems with green coffee extract. Int. J. Food Prop. 17(7), 1529-1546 (2013). doi:10. 1080/10942912.2012.723235

12. A. Hoppe, S. Jung, A. Patnaik, M. G. Zeece, Effect of high pressure treatment on egg white protein digestibility and peptide products. Innovative Food Sci. Emerg. Technol. 17, 54-62 (2013). doi:10. 1016/j.ifset.2012.11.003

13. E. T. Mertz, M. M. Hassen, C. Cairns-Whittern, A. W. Kirleis, L. $\mathrm{Tu}$, J. D. Axtell, Pepsin digestibility of proteins in sorghum and other major cereals. Proc. Natl. Acad. Sci. U. S. A. 81(1), 1-2 (1984)

14. Pelgrom PJM, Wang J, Boom RM, Schutyser MAI (2015) Pre- and post-treatment enhance the protein enrichment from milling and air classification of legumes. J. Food Eng. 155 (0):53-61. doi:10.1016/ j.jfoodeng.2015.01.005

15. R. Becker, E. L. Wheeler, K. Lorenz, A. E. Stafford, O. K. Grosjean, A. A. Betschart, R. M. Saunders, A compositional study 
of Amaranth Grain. J. Food Sci. 46(4), 1175-1180 (1981). doi:10. 1111/j.1365-2621.1981.tb03018.x

16. Castellani OF, E. N. Martínez, M. C. Añón, Structural modifications of an Amaranth globulin induced by $\mathrm{pH}$ and $\mathrm{NaCl}$. J. Agric. Food Chem. 46(12), 4846-4853 (1998). doi:10.1021/jf9802427

17. F. Kong, R. P. Singh, Modes of disintegration of solid foods in simulated gastric environment. Food Biophysics 4(3), 180-190 (2009). doi:10.1007/s11483-009-9116-9

18. Q. Luo, R. M. Boom, A. E. M. Janssen, Digestion of protein and protein gels in simulated gastric environment. LWT Food Sci. Technol. 63(1), 161-168 (2015). doi:10.1016/j.lwt.2015.03.087

19. E. J. Casey, K. J. Laidler, The kinetics and mechanism of the heat inactivation of Pepsin1. J. Am. Chem. Soc. 73(4), 1455-1457 (1951). doi:10.1021/ja01148a015

20. G. Avila Ruiz, W. Xiao, M. van Boekel, M. Minor, M. Stieger, Effect of extraction $\mathrm{pH}$ on heat-induced aggregation, gelation and microstructure of protein isolate from quinoa (Chenopodium quinoa Willd). Food Chem. (2016). doi:10.1016/j.foodchem.2016.04.052

21. G. S. Chauhan, W. Cui, N. A. M. Eskin, Effect of saponin on the surface properties of quinoa proteins. Int. J. Food Prop. 2(1), 13-22 (1999). doi:10.1080/10942919909524586

22. Lindeboom N (2005) Studies on the characterization, biosynthesis and isolation of starch and protein from quinoa (Chenopodium quinoa Willd.). University of Saskatchewan, Canada

23. R. E. Aluko, E. Monu, Functional and bioactive properties of quinoa seed protein hydrolysates. J. Food Sci. 68(4), 1254-1258 (2003)

24. E. N. Martínez, M. C. Añón, Composition and structural characterization of Amaranth protein isolates. An electrophoretic and calorimetric study. J. Agric. Food Chem. 44(9), 2523-2530 (1996). doi: $10.1021 / \mathrm{j} 960169 \mathrm{p}$

25. M. I. Molina, S. Petruccelli, M. C. Añón, Effect of pH and ionic strength modifications on thermal denaturation of the $11 \mathrm{~S}$ globulin of sunflower (Helianthus annuus). J. Agric. Food Chem. 52(19), 6023-6029 (2004). doi:10.1021/jf0494175

26. C. Brinegar, S. Goundan, Isolation and characterization of chenopodin, the 118 seed storage protein of quinoa (Chenopodium quinoa). J. Agric. Food Chem. 41(2), 182-185 (1993)

27. J. E. Kinsella, S. Damodaran, B. German, A. M. A. L. Wilcke, $V$ physicochemical and functional properties of oilseed proteins with emphasis on soy proteins (New Protein Foods. Academic Press, In, 1985), pp. 107-179. doi:10.1016/B978-0-12-054805-7.50012-9

28. S. Utsumi, S. Damodaran, J. E. Kinsella, Heat-induced interactions between soybean proteins: preferential association of $11 \mathrm{~S}$ basic subunits and. beta. subunits of 7S. J. Agric. Food Chem. 32(6), 1406-1412 (1984). doi:10.1021/jf00126a047

29. W. J. Wolf, T. Tamura, Heat denaturation of soybean $11 \mathrm{~S}$ protein. Cereal Chem. 46, 331-343 (1969)

30. P. J. M. Pelgrom, J. A. M. Berghout, A. J. van der Goot, R. M. Boom, M. A. I. Schutyser, Preparation of functional lupine protein fractions by dry separation. LWT - Food Science and Technology 59(2, Part 1), 680-688 (2014). doi:10.1016/j.lwt.2014.06.007

31. R. Zhao, S. R. Bean, B. P. Ioerger, D. Wang, D. L. Boyle, Impact of mashing on sorghum proteins and its relationship to ethanol fermentation. J. Agric. Food Chem. 56(3), 946-953 (2008). doi:10. 1021/jf072590r

32. L. Lev Elkonin, J. Italianskaya, I. Fadeeva, in Gel electrophoresis advanced techniques, ed by S. Mageldin. Gel electrophoresis as a tool to study polymorphism and nutritive value of the seed storage proteins in the Grain sorghum (InTech, Russia, 2012), pp. 463-478

33. A. Bhargava, S. Srivastava, in Quinoa - botany, ed by A. Bhargava, S. Srivastava. Chemistry (Production and Uses. CABI, Oxfordshire, 2013), pp. 185-239 